\title{
A QUANTITATIVE STUDY OF THE OXIDATION OF GLUCOSE IN NORMAL AND DIABETIC MEN
}

\author{
By J. M. SHELDON, M. W. JOHNSTON AND L. H. NEWBURGH \\ (From the Department of Internal Medicine, Medical School, University of Michigan, \\ Ann Arbor)
}

(Received for publication July 23, 1937)

There have been two schools of thought as to the cause of diabetes mellitus; one group holding to the lessened oxidation, and another group believing in the overproduction theory of the disease. The information concerning oxidation has been based largely upon repeated determinations of respiratory gaseous exchange at short intervals; the total period being calculated on the assumption that the process was sufficiently uniform to permit the estimation of the total glucose oxidized from a series of samples. The overproduction theory is based on indirect findings, which have not convinced most workers that fat is converted to carbohydrate to any significant extent by the diabetic individual. In addition, there has been much discussion as to whether a diabetic should be fed a diet high in carbohydrate, or one high in fat and low in carbohydrate. The argument in this instance has, in the main, been dependent upon clinical observations. It would seem that the use of a respiration chamber which would permit the continuous measurement of the oxidative processes might clarify these questions.

In this study a respiration chamber (1) for continuous measurement of the respiratory gases has been used. Standard open circuit indirect calorimetry has been employed. Gas analysis has been carried out by the technique of Carpenter (2). The rapidity of mixture of gases has been checked by introducing known quantities of carbon dioxide into the respiration chamber and then removing gas samples at short intervals. It has been found that a complete mixture of gases occurs within three minutes. Alcohol checks (1) have repeatedly given recoveries of better than 99 per cent of the theoretical values.

All of the normal and diabetic subjects have been prepared for three or more days on a simple diet of known composition. Approximately sufficient calories for maintenance were given. The dietary protein has been adequate in all instances.
The diabetics have been given the same quantity of protein as their comparative controls. The quantity of carbohydrate has been varied in the preparatory diet from 21 to 500 grams, and the fat has been adjusted isocalorically. The diabetics were first studied following a long period of control in which their blood sugars were within normal limits. The same diabetics were then investigated after a period of 23 to 35 days of constant hyperglycemia and glycosuria. In some instances, the same diabetics were again studied following a second short period when they were aglycosuric and their fasting blood sugars were kept normal, either by dietary adjustment or by the use of insulin. The amounts of dextrose given at the beginning of the oxidative study have been varied from 0 to 200 grams.

The subjects were placed in the respiration chamber on the evening of the last preparatory day. The following morning, 12 to 14 hours after their last meal, they arose, emptied their bladders, and drank $400 \mathrm{cc}$. of distilled water, or an equivalent quantity of fluid containing dextrose. They then returned to bed where they quietly reclined for the next four hours. The carbon dioxide and oxygen determinations were begun when the subject had returned to bed. At the end of the four-hour period the subject would again arise and empty the bladder. The carbon dioxide and oxygen determinations were then stopped.

The urine of the diabetics and normal subjects collected during the four-hour oxidative period was routinely tested for ketone bodies with a 10 per cent aqueous solution of ferric chloride. In all instances the test was negative.

The calculations of glucose oxidized were made by the usual standard method (3).

\section{RESULTS}

When three normal male subjects were studied in the fasting state, the amount of carbohydrate 
TABLE I

Normals

The effect of increasing the carbohydrate of the preparatory diet upon the oxidation of glucose

\begin{tabular}{|c|c|c|c|c|c|c|c|c|c|}
\hline \multirow{3}{*}{$\begin{array}{c}\text { Ex- } \\
\text { peri- } \\
\text { ment } \\
\text { num- } \\
\text { ber }\end{array}$} & \multirow{3}{*}{ Sub- } & \multicolumn{3}{|c|}{ Diet } & \multirow{3}{*}{$\begin{array}{l}\text { Total } \\
\text { R.Q. }\end{array}$} & \multirow{3}{*}{$\begin{array}{l}\text { Total } \\
\text { oxy- } \\
\text { gen }\end{array}$} & \multirow{3}{*}{$\begin{array}{c}\text { Nitro- } \\
\text { gen } \\
\text { of } \\
\text { urine }\end{array}$} & \multirow{3}{*}{$\begin{array}{c}\text { Heat } \\
\text { pro- } \\
\text { duc- } \\
\text { tion }\end{array}$} & \multirow{3}{*}{$\begin{array}{l}\text { Glu- } \\
\text { cose } \\
\text { oxi- } \\
\text { dized }\end{array}$} \\
\hline & & \multicolumn{2}{|c|}{ Preparation } & \multirow{2}{*}{$-\frac{\begin{array}{c}\text { In } \\
\text { cham- } \\
\text { ber }\end{array}}{}=$} & & & & & \\
\hline & & $\begin{array}{l}\text { Cal- } \\
\text { ories }\end{array}$ & $\begin{array}{l}\text { Car- } \\
\text { bohy- } \\
\text { drate }\end{array}$ & & & & & & \\
\hline $\begin{array}{l}1 \\
2 \\
3 \\
4 \\
5 \\
6 \\
7 \\
8\end{array}$ & $\begin{array}{l}\text { C.F. } \\
\text { C.F. } \\
\text { D.D. } \\
\text { C.F. } \\
\text { B.D. } \\
\text { B.D. } \\
\text { B.D. } \\
\text { J.M. }\end{array}$ & $\begin{array}{l}2000 \\
2742 \\
2742 \\
2750 \\
2530 \\
2750 \\
2687 \\
3500\end{array}$ & $\begin{array}{c}\text { grams } \\
21 \\
53 \\
53 \\
100 \\
100 \\
201 \\
202 \\
500\end{array}$ & $\begin{array}{c}\text { grams } \\
0 \\
0 \\
0 \\
0 \\
0 \\
0 \\
0 \\
0\end{array}$ & $\begin{array}{l}.764 \\
.784 \\
.790 \\
.773 \\
.779 \\
.792 \\
.793 \\
.824\end{array}$ & $\begin{array}{l}\text { liters } \\
66.79 \\
65.47 \\
56.62 \\
64.66 \\
57.97 \\
59.14 \\
60.64 \\
75.44\end{array}$ & $\begin{array}{l}\text { grams } \\
2.60 \\
2.25 \\
2.41 \\
1.84 \\
2.12 \\
2.23 \\
1.99 \\
2.07\end{array}$ & \begin{tabular}{|c|} 
cal- \\
ories \\
312 \\
309 \\
268 \\
304 \\
273 \\
279 \\
288 \\
360
\end{tabular} & $\begin{array}{l}\text { grams } \\
10.6 \\
17.3 \\
20.3 \\
15.3 \\
14.0 \\
17.4 \\
18.7 \\
35.2\end{array}$ \\
\hline 9 & C.F. & 2000 & 21 & 25 & .777 & 62.82 & 2.33 & 295 & 14.7 \\
\hline $\begin{array}{l}10 \\
11 \\
12 \\
13 \\
14 \\
15\end{array}$ & $\begin{array}{l}\text { C.F. } \\
\text { B.D. } \\
\text { C.F. } \\
\text { B.D. } \\
\text { B.D. } \\
\text { B.D. }\end{array}$ & $\begin{array}{l}2742 \\
1980 \\
2750 \\
2750 \\
2750 \\
2750\end{array}$ & $\begin{array}{r}53 \\
50 \\
100 \\
100 \\
201 \\
201\end{array}$ & $\begin{array}{l}\mathbf{5 0} \\
\mathbf{5 0} \\
\mathbf{5 0} \\
\mathbf{5 0} \\
\mathbf{5 0} \\
\mathbf{5 0}\end{array}$ & $\begin{array}{l}.804 \\
.845 \\
.833 \\
.904 \\
.889 \\
.870\end{array}$ & $\begin{array}{l}70.05 \\
53.06 \\
67.77 \\
56.60 \\
63.09 \\
58.18\end{array}$ & $\begin{array}{l}2.25 \\
2.38 \\
2.28 \\
2.43 \\
2.46 \\
1.87\end{array}$ & $\begin{array}{l}332 \\
253 \\
323 \\
274 \\
305 \\
281\end{array}$ & $\begin{array}{l}25.6 \\
27.8 \\
33.2 \\
44.9 \\
46.6 \\
39.2\end{array}$ \\
\hline $\begin{array}{l}16 \\
17 \\
18\end{array}$ & $\begin{array}{l}\text { C.F. } \\
\text { B.D. } \\
\text { B.D. }\end{array}$ & $\begin{array}{l}2750 \\
2627 \\
2750\end{array}$ & $\begin{array}{l}100 \\
101 \\
199\end{array}$ & $\begin{array}{l}100 \\
100 \\
100\end{array}$ & $\begin{array}{l}.826 \\
.899 \\
.921\end{array}$ & $\begin{array}{l}71.66 \\
61.37 \\
60.46\end{array}$ & $\begin{array}{l}2.05 \\
2.01 \\
2.27\end{array}$ & $\begin{array}{l}341 \\
298 \\
295\end{array}$ & $\begin{array}{l}35.1 \\
49.1 \\
53.9\end{array}$ \\
\hline $\begin{array}{l}19 \\
20\end{array}$ & $\begin{array}{l}\text { B.D. } \\
\text { B.D. }\end{array}$ & $\begin{array}{l}2627 \\
2742\end{array}$ & $\begin{array}{l}101 \\
204\end{array}$ & $\begin{array}{l}200 \\
200\end{array}$ & $\begin{array}{l}.887 \\
.965\end{array}$ & $\begin{array}{l}62.38 \\
68.05\end{array}$ & $\begin{array}{l}2.22 \\
2.84\end{array}$ & $\begin{array}{l}302 \\
333\end{array}$ & $\begin{array}{l}45.5 \\
68.9\end{array}$ \\
\hline
\end{tabular}

TABLE II

Normals

The effect of increasing the amount of glucose at the beginning of the period of oxidation when the carbohydrate of the preparation was constant

\begin{tabular}{|c|c|c|c|c|c|c|c|c|c|}
\hline \multirow{3}{*}{$\begin{array}{c}\text { Ex- } \\
\text { peri- } \\
\text { ment } \\
\text { num- } \\
\text { ber }\end{array}$} & \multirow{3}{*}{$\begin{array}{l}\text { Sub- } \\
\text { ject }\end{array}$} & \multicolumn{3}{|c|}{ Diet } & \multirow{3}{*}{$\begin{array}{l}\text { Total } \\
\text { R. Q. }\end{array}$} & \multirow{3}{*}{$\begin{array}{l}\text { Total } \\
\text { oxy- } \\
\text { gen }\end{array}$} & \multirow{3}{*}{$\begin{array}{c}\text { Nitro- } \\
\text { gen } \\
\text { of } \\
\text { urine }\end{array}$} & \multirow{3}{*}{$\begin{array}{l}\text { Heat } \\
\text { pro- } \\
\text { duc- } \\
\text { tion }\end{array}$} & \multirow{3}{*}{$\begin{array}{l}\text { Glu- } \\
\text { cose } \\
\text { oxi- } \\
\text { dized }\end{array}$} \\
\hline & & \multicolumn{2}{|c|}{ Preparation } & \multirow{2}{*}{$\frac{\begin{array}{c}\text { In } \\
\text { cham- } \\
\text { ber }\end{array}}{}$} & & & & & \\
\hline & & $\begin{array}{l}\text { Cal- } \\
\text { ories }\end{array}$ & $\begin{array}{l}\text { Car- } \\
\text { bohy- } \\
\text { drate }\end{array}$ & & & & & & \\
\hline & & & grams & grams & & liters & grams & $\begin{array}{c}\text { cal- } \\
\text { ories }\end{array}$ & grams \\
\hline $\begin{array}{l}13 \\
12 \\
17 \\
16 \\
19 \\
14 \\
15 \\
18 \\
20\end{array}$ & $\begin{array}{l}\text { B.D. } \\
\text { C.F. } \\
\text { B.D. } \\
\text { C.F. } \\
\text { B.D. } \\
\text { B.D. } \\
\text { B.D. } \\
\text { B.D. } \\
\text { B.D. }\end{array}$ & $\begin{array}{l}2750 \\
2750 \\
2627 \\
2750 \\
2627 \\
2750 \\
2750 \\
2750 \\
2742\end{array}$ & $\begin{array}{l}100 \\
100 \\
101 \\
100 \\
101 \\
201 \\
201 \\
199 \\
204\end{array}$ & $\begin{array}{r}50 \\
50 \\
100 \\
100 \\
200 \\
50 \\
50 \\
100 \\
200\end{array}$ & $\begin{array}{l}.904 \\
.833 \\
.899 \\
.826 \\
.887 \\
.889 \\
.870 \\
.921 \\
.965\end{array}$ & $\begin{array}{l}56.60 \\
67.77 \\
61.37 \\
71.66 \\
62.38 \\
63.09 \\
58.18 \\
60.46 \\
68.05\end{array}$ & $\begin{array}{l}2.43 \\
2.28 \\
2.01 \\
2.05 \\
2.22 \\
2.46 \\
1.87 \\
2.27 \\
2.84\end{array}$ & $\begin{array}{l}274 \\
323 \\
298 \\
341 \\
302 \\
305 \\
281 \\
295 \\
333\end{array}$ & $\begin{array}{l}44.9 \\
33.2 \\
49.1 \\
35.1 \\
45.5 \\
46.6 \\
39.2 \\
53.9 \\
68.9\end{array}$ \\
\hline
\end{tabular}

TABLE III

Normals

The effect of simultaneously increasing the carbohydrate in the preparatory diet and at the beginning of the oxidation period

\begin{tabular}{|c|c|c|c|c|c|c|c|c|c|}
\hline \multirow{3}{*}{$\begin{array}{l}\text { Ex- } \\
\text { peri- } \\
\text { ment } \\
\text { num- } \\
\text { ber }\end{array}$} & \multirow{3}{*}{ Sub- } & \multicolumn{3}{|c|}{ Diet } & \multirow{3}{*}{$\left|\begin{array}{l}\text { Total } \\
\text { R. Q. }\end{array}\right|$} & \multirow{3}{*}{$\begin{array}{l}\text { Total } \\
\text { oxy- } \\
\text { gen }\end{array}$} & \multirow{3}{*}{$\begin{array}{c}\text { Nitro- } \\
\text { gen } \\
\text { of } \\
\text { urine }\end{array}$} & \multirow{3}{*}{$\begin{array}{l}\text { Heat } \\
\text { pro- } \\
\text { duc- } \\
\text { tion }\end{array}$} & \multirow{3}{*}{$\begin{array}{l}\text { Glu- } \\
\text { cose } \\
\text { oxi- } \\
\text { dized }\end{array}$} \\
\hline & & \multicolumn{2}{|c|}{ Preparation } & \multirow{2}{*}{$\frac{\begin{array}{c}\text { In } \\
\text { cham- } \\
\text { ber }\end{array}}{-}$} & & & & & \\
\hline & & $\begin{array}{l}\text { Cal- } \\
\text { ories }\end{array}$ & $\begin{array}{l}\text { Car- } \\
\text { bohy- } \\
\text { drate }\end{array}$ & & & & & & \\
\hline & & & grams & grams & & liters & grams & $\begin{array}{c}\text { cal- } \\
\text { ories }\end{array}$ & grams \\
\hline $\begin{array}{l}12 \\
13 \\
14 \\
15 \\
16 \\
17 \\
18\end{array}$ & $\begin{array}{l}\text { C.F. } \\
\text { B.D. } \\
\text { B.D. } \\
\text { B.D. } \\
\text { C.F. } \\
\text { B.D. } \\
\text { B.D. }\end{array}$ & $\begin{array}{l}2750 \\
2750 \\
2750 \\
2750 \\
2750 \\
2627 \\
2750\end{array}$ & $\begin{array}{l}100 \\
100 \\
201 \\
201 \\
100 \\
101 \\
199\end{array}$ & $\begin{array}{r}50 \\
50 \\
50 \\
50 \\
100 \\
100 \\
100\end{array}$ & $\begin{array}{l}.833 \\
.904 \\
.889 \\
.870 \\
.826 \\
.899 \\
.921\end{array}$ & $\begin{array}{l}67.77 \\
56.60 \\
63.09 \\
58.18 \\
71.66 \\
61.37 \\
60.46\end{array}$ & $\begin{array}{l}2.28 \\
2.43 \\
2.46 \\
1.87 \\
2.05 \\
2.01 \\
2.27\end{array}$ & $\begin{array}{l}323 \\
274 \\
305 \\
281 \\
341 \\
298 \\
295\end{array}$ & $\begin{array}{l}33.2 \\
44.9 \\
46.6 \\
39.2 \\
35.1 \\
49.1 \\
53.9\end{array}$ \\
\hline
\end{tabular}

TABLE IV

Diabetic patients

The effect of increasing the glucose at the beginning of the period of oxidation upon the oxidation of glucose

\begin{tabular}{|c|c|c|c|c|c|c|c|c|c|}
\hline \multirow{3}{*}{$\begin{array}{l}\text { Ex- } \\
\text { peri- } \\
\text { ment } \\
\text { num- } \\
\text { ber }\end{array}$} & \multirow{3}{*}{ Sub- } & \multicolumn{3}{|c|}{ Diet } & \multirow{3}{*}{$\begin{array}{l}\text { Total } \\
\text { R. Q. }\end{array}$} & \multirow{3}{*}{$\begin{array}{l}\text { Total } \\
\text { oxy- } \\
\text { gen }\end{array}$} & \multirow{3}{*}{$\begin{array}{c}\text { Nitro- } \\
\text { gen } \\
\text { of } \\
\text { urine }\end{array}$} & \multirow{3}{*}{$\begin{array}{l}\text { Heat } \\
\text { pro- } \\
\text { duc- } \\
\text { tion }\end{array}$} & \multirow{3}{*}{$\begin{array}{l}\text { Glu- } \\
\text { cose } \\
\text { oxi- } \\
\text { dized }\end{array}$} \\
\hline & & \multicolumn{2}{|c|}{$\begin{array}{c}\text { Prepara- } \\
\text { tion }\end{array}$} & \multirow{2}{*}{$\begin{array}{c}\begin{array}{c}\text { In } \\
\text { cham- } \\
\text { ber }\end{array} \\
\begin{array}{c}\text { Glu- } \\
\text { cose }\end{array}\end{array}$} & & & & & \\
\hline & & $\begin{array}{l}\text { Cal- } \\
\text { ories }\end{array}$ & $\begin{array}{l}\text { Car- } \\
\text { bohy- } \\
\text { drate }\end{array}$ & & & & & & \\
\hline $\begin{array}{l}21 \\
22 \\
23 \\
24\end{array}$ & $\begin{array}{l}\text { M.M.** } \\
\text { M.M. } \\
\text { M.M. } \\
\text { M.M. }\end{array}$ & $\begin{array}{l}2000 \\
2000 \\
2000 \\
2000\end{array}$ & $\begin{array}{c}\text { grams } \\
21 \\
21 \\
21 \\
21\end{array}$ & $\begin{array}{c}\text { grams } \\
0 \\
25 \\
25 \\
50\end{array}$ & $\begin{array}{l}.732 \\
.757 \\
.768 \\
.753\end{array}$ & \begin{tabular}{|c|} 
liters \\
61.69 \\
59.16 \\
59.22 \\
62.93
\end{tabular} & \begin{tabular}{|c|} 
grams \\
2.07 \\
1.83 \\
1.67 \\
2.29
\end{tabular} & $\begin{array}{c}\text { calories } \\
287 \\
277 \\
279 \\
294\end{array}$ & $\begin{array}{c}\text { grams } \\
0.7 \\
8.7 \\
12.2 \\
7.5\end{array}$ \\
\hline $\begin{array}{l}25 \\
26 \\
27 \\
288 \\
298 \\
305 \\
31 \|\end{array}$ & $\begin{array}{l}\text { R.S.t } \\
\text { R.S. } \\
\text { R.S. } \\
\text { R.S. } \\
\text { R.S. } \\
\text { R.S. } \\
\text { R.S. }\end{array}$ & $\begin{array}{l}2700 \\
2700 \\
2700 \\
2780 \\
2780 \\
2780 \\
2780\end{array}$ & $\begin{array}{r}40 \\
40 \\
40 \\
130 \\
130 \\
130 \\
130\end{array}$ & $\begin{array}{r}0 \\
0 \\
50 \\
0 \\
50 \\
100 \\
100\end{array}$ & $\begin{array}{l}.774 \\
.767 \\
.780 \\
.843 \\
.822 \\
.791 \\
.806\end{array}$ & \begin{tabular}{|l|}
68.33 \\
73.61 \\
72.17 \\
59.53 \\
63.87 \\
55.73 \\
57.97
\end{tabular} & \begin{tabular}{|l}
1.34 \\
1.65 \\
2.47 \\
1.70 \\
2.39 \\
2.44 \\
2.25
\end{tabular} & $\begin{array}{l}323 \\
347 \\
340 \\
286 \\
304 \\
332 \\
338\end{array}$ & $\begin{array}{l}17.5 \\
16.2 \\
17.7 \\
25.2 \\
26.5 \\
21.1 \\
24.4\end{array}$ \\
\hline $\begin{array}{l}32 \\
33 \\
34 \\
359 \\
369 \\
379\end{array}$ & $\begin{array}{l}\text { W.H.t } \\
\text { W.H. } \\
\text { w.H. } \\
\text { w.H. } \\
\text { W.H. } \\
\text { W.H. }\end{array}$ & \begin{tabular}{|l|}
2600 \\
2600 \\
2600 \\
2760 \\
2760 \\
2760
\end{tabular} & $\begin{array}{l}100 \\
100 \\
100 \\
226 \\
226 \\
226\end{array}$ & $\begin{array}{r}0 \\
50 \\
100 \\
0 \\
50 \\
100\end{array}$ & $\begin{array}{l}.763 \\
.758 \\
.801 \\
.803 \\
.820 \\
.818\end{array}$ & \begin{tabular}{|l|}
56.42 \\
58.37 \\
56.19 \\
61.77 \\
60.90 \\
58.10
\end{tabular} & $\begin{array}{l}1.46 \\
1.76 \\
2.10 \\
3.20 \\
3.04 \\
3.11\end{array}$ & $\begin{array}{l}266 \\
274 \\
266 \\
290 \\
288 \\
274\end{array}$ & $\begin{array}{r}10.3 \\
9.4 \\
18.9 \\
19.3 \\
23.9 \\
21.5\end{array}$ \\
\hline
\end{tabular}

* M.M. tolerance of $\mathbf{5 5}$ grams of available glucose.

† R.S. tolerance of 90 grams of available glucose.

\pm W.H. tolerance of 140 grams of available glucose.

$\$$ Glycosuria and hyperglycemia for 35 days previous to oxidation study.

II Controlled with insulin with normal fasting blood sugars for $\mathbf{1 0}$ days previous to oxidation study.

II Glycosuria and hyperglycemia for 23 days previous to oxidation study. 


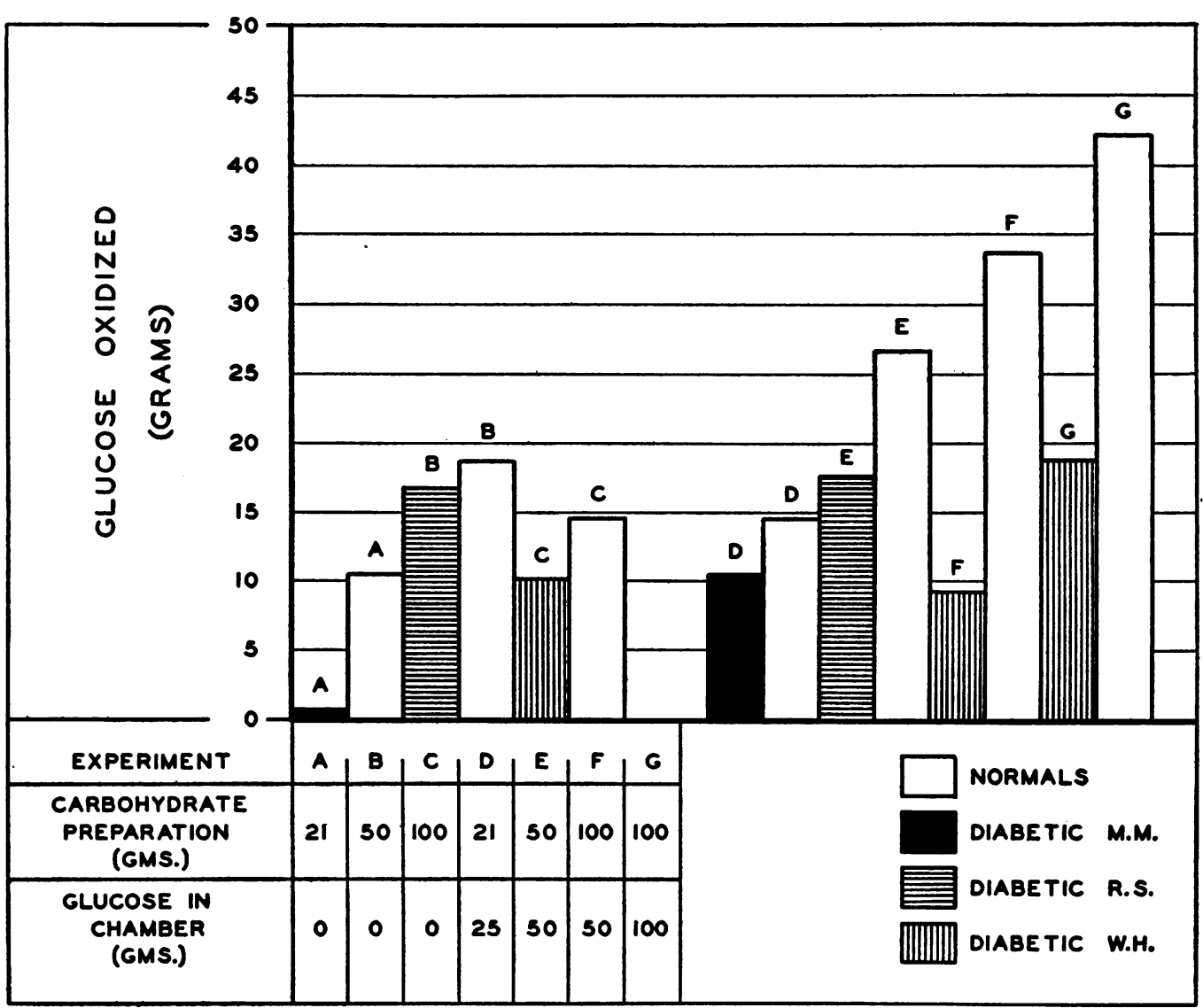

Fig. 1. A Comparison of the Oxidation of Glucose in Diabetic Subjects and Normal Subjects

oxidized in the four-hour period became larger as the carbohydrate of the preparatory diet was increased (Table I). This effect was consistently obtained when the carbohydrate in the preparatory diet was varied between 25 and 500 grams. Further, when the glucose was ingested at the beginning of the experimental period in amounts from 50 to 200 grams, even though the carbohydrate preparation had been the same, the oxidation of glucose was increased (Table II). When both the carbohydrate of the preparatory and chamber periods were simultaneously increased, the oxidation of glucose was additive (Table III).

The three male diabetics studied were aged 19, 22 and 26. They were free of any disease other than the diabetes mellitus. All of them had been under observation at the University Hospital for one or more years. The results of the oxidation study in these patients, performed after 14 to 21 days of complete control, are summarized in Table IV. The amount of glucose oxidized in the four hours was dependent upon the severity of the diabetic's disease. However, the response to increasing the glucose of the chamber period is similar to the response of the normal subjects, but quantitatively reduced. Figure 1 gives a graphic representation of the quantitative difference between the individudal diabetic subjects and the normals. In this Figure, $A$ and $D$ are from one diabetic, $B$ and $E$ from a second diabetic and $C, F$ and $G$ from a third diabetic. When the same diabetics were studied after a period of 23 to 35 days of constant hyperglycemia and glycosuria, the amount of glucose oxidized in four hours stayed at a constant level (Experiments 28, 29, 30, 35, 36 and 37 , Table IV), even though the glucose of the chamber period was increased from 0 to 100 grams. Emphasis should be placed on the inability to increase oxidation of glucose in response to the ingestion of increased amounts of glucose, a marked contrast to the normal controls who oxidized more glucose when they took more 
of it. It was also observed that increasing the carbohydrate preparation from two to three times above the tolerance of the diabetics resulted in but slight increase in the amount of glucose oxidized. This slight increase may be attributed to the associated hyperglycemia, which produced a maximum stimulation of the mechanism for the utilization of carbohydrate. Once the maximum stimulation has been reached, further ingestion of glucose can never result in additional oxidation. Experiment 31 (Table IV) further substantiates this view. Diabetic R. S., while taking a diet containing 130 grams of carbohydrate, had a glycosuria that exceeded 60 grams each 24 hours when insulin was not used. This same diabetic was given insulin in amounts to keep him aglycosuric for 10 days. Then food was withheld and insulin discontinued 12 hours before the oxidative study. In this instance 24 grams of glucose were oxidized, an amount similar to the oxidation while on the same diet without insulin. From the above data (Table IV), it is apparent that carbohydrate in excess of the diabetics' oxidatixe ability was never beneficial to those diabetics studied nor was it possible to benefit the mechanism that utilizes carbohydrate by the previous use of insulin.

\section{CONCLUSIONS}

The fasting normal subject oxidizes increasing amounts of glucose in response to increasing quantities of carbohydrate in the preparatory diet. He likewise oxidizes more glucose during the four hours in response to increasing ingestion of dextrose at the beginning of the period even though the preparation has been the same. When both sources of carbohydrate are simultaneously increased, the oxidation of glucose is additive. The response of the diabetic is qualitatively similar but quantitatively smaller. The diabetics' ability to oxidize glucose was directly related to the severity of the disease. Carbohydrate, in excess of the ability of these diabetics to oxidize it, was of no benefit.

\section{BIBLIOGRAPHY}

1. Newburgh, L. H., Johnston, M. W., Wiley, F. H., Sheldon, J. M., and Murrill, W. A., A respiration chamber for use with human subjects. J. Nutrition, 1937, 13, 193.

2. Carpenter, T. M., Ein Apparat Zur Analyse Von Gasen aus Respirationskammern für Menschen und Tiere. In Handbuch der biologischen Arbeitsmethoden. 1937, Abt. IV, Teil 13, S. 593.

3. Lusk, Graham, The Elements of the Science of Nutrition. W. B. Saunders Co., Philadelphia, 1917, 3d ed., p. 62. 